\title{
ERRATA
}

The following errata are to be made in the article "On the Representation of Tones in Oriental Languages" appearing in the Journal for October, $1920:-$ p. 455, footnote, 1. 2, for "Anthropus" read "Anthropos". p. 465, wherever the word "Quocsngu" occurs, correct it to "Quoc^ngï".

\section{Proceedings of the Society of Biblical Archæology}

Back numbers of the Proceedings of the Society of Biblical Archæology are still in great demand, especially Vols. 30-38. Any numbers that members can spare will be most gratefully accepted.

\section{Hakluyt Society's Publications}

If any member has copies of Hakluyt Society's publications, Original Series, Nos. 1-25, 27-41, 43-52; also Series II, Vols. 5 and 29 , they would be gratefully accepted for the Library.

\section{THE SARROSH K. R. CAMA MEMORIAL PRIZE}

The Committee of the K. R. Cama Oriental Institute invite competitive essays for "The Sarrosh K. R. Cama Prize" of the value of Rs. 225 on the following subject: "Life of Zoroaster as based on the Avesta."

The essays should be typewritten or written in a neat, legible hand, and should reach the Honorary Secretaries the K. R. Cama Oriental Institute, Hornby Road, Fort, Bombay, on or before July 15, 1921. Each essay should be designated by a motto instead of the writer's name, and should be accompanied by a sealed cover containing the name of the competitor and his Post Office address. The competition is open to both Zoroastrians and nonZoroastrians. 